\title{
Post-exercise carbohydrate plus whey protein hydrolysates supplementation increases skeletal muscle glycogen level in rats
}

\author{
Atsushi Kanda ${ }^{1 *}$, Masashi Morifuji ${ }^{1}$, Jinichiro Koga ${ }^{1}$, Kentaro Kawanaka ${ }^{2}$, Mitsuru Higuchi $^{3}$ \\ From International Society of Sports Nutrition; 7th Annual ISSN Conference and Expo \\ Clearwater Beach, FL, USA. 24-26 June 2010
}

\section{Background}

Recent studies have shown that co-ingestion of carbohydrate and protein is more effective than carbohydrate alone for replenishing muscle glycogen after exercise. However, it remains unclear whether the source or degree of hydrolysis of dietary protein influences postexercise glycogen accumulation. The aim of this study was to compare the effect of dietary protein type on skeletal muscle glycogen levels in the post-exercise phase, and to investigate the effects of post-exercise carbohydrate and protein supplementation on phosphorylated enzymes of Akt/PKB and atypical PKCs.

\section{Methods}

Male Sprague-Dawley rats, pre-trained for 3 days, swam with a $2 \%$ load of body weight for 4 hours to deplete skeletal muscle glycogen. Immediately after the glycogen-depleting exercise, one group of rats was killed, whereas the other groups were given solutions of either glucose or glucose plus protein (whey protein, whey protein hydrolysates (WPH), casein hydrolysates or branched-chain amino acid (BCAA)). After 2 hours, the rats were killed, followed by analysis of glycogen content and phosphorylated enzymes of Akt/PKB and atypical PKCs in the triceps muscles.

\section{Results}

WPH caused significant increases $(p<0.05)$ in skeletal muscle glycogen level $(5.01+/-0.24 \mathrm{mg} / \mathrm{g})$, compared with whey protein $(4.23+/-0.24 \mathrm{mg} / \mathrm{g})$, BCAA $(3.92$ $+/-0.18 \mathrm{mg} / \mathrm{g}$ ) or casein hydrolysates $(2.73+/-0.22 \mathrm{mg} / \mathrm{g})$. Post-exercise ingestion of glucose plus WPH caused

\footnotetext{
Food and Health R\&D Laboratories, Meiji Seika Kaisha Ltd., 5-3-1 Chiyoda, Sakado-shi, Saitama 350-0289, Japan

Full list of author information is available at the end of the article
}

significant increases $(p<0.05)$ in both phosphorylated Akt/PKB (131\%) and phosphorylated PKC $\zeta(154 \%)$ levels compared with glucose only. There was a significant positive correlation between skeletal muscle glycogen content and phosphorylated Akt/PKB ( $r=0.674, p<$ $0.001)$ and PKC $\zeta(r=0.481, p=0.017)$ in the triceps muscles.

\section{Conclusion}

It is concluded that post-exercise supplementation with carbohydrate and WPH increases skeletal muscle glycogen recovery by activating key enzymes such as Akt/ PKB and atypical PKCs.

\section{Author details}

${ }^{1}$ Food and Health R\&D Laboratories, Meiji Seika Kaisha Ltd., 5-3-1 Chiyoda, Sakado-shi, Saitama 350-0289, Japan. . 2 Department of Health and Nutrition, Niigata University of Health and Welfare, 1398 Shimamicho, Kita-ku, Niigata, Niigata 950-3198, Japan . ${ }^{3}$ Faculty of Sport Sciences, Waseda University, 135-1 Horinouchi, Tokorozawa, Saitama 359-1165, Japan.

Published: 15 September 2010

doi:10.1186/1550-2783-7-S1-P19

Cite this article as: Kanda et al:: Post-exercise carbohydrate plus whey protein hydrolysates supplementation increases skeletal muscle glycogen level in rats. Journal of the International Society of Sports Nutrition 2010 7(Suppl 1):P19. 